\title{
Relationship between Organizational Trust and Organizational Innovation: Case Study of the Payam Nour University
}

\author{
Ali Jamshidi \\ Department of Management, Payame Noor University, PO BOX 19395 - 3697, Tehran, IRAN \\ Ali100189@yahoo.com
}

Keywords: Organizational trust, Organizational innovation, Innovative or Transformational leadership.

\begin{abstract}
The present research was done to analyze the relationship between organizational trust and organizational innovation at Payam Nour University in Tehran Province. To collect data related to organizational trust, Payne questionnaire was used. Organizational innovation data were collected by a researcher-developed questionnaire. The reliability of both of which based on Alfa Cronbach coefficient was $91 \%$ and $86 \%$ respectively. To analyze data, Pearson correlation test and step-by step regression were applied. The result of correlation test showed that there is positive and significant relationship between organizational trust and all its dimensions with organizational innovation. The results of structural equation modeling were collected by 231 questionnaires and suggest that innovative leadership and organizational trust have relation with organizational innovation. In conclusion, the results are analyzed and some suggestions are made to improve innovation capability in the organization of the target population.
\end{abstract}

\section{Introduction}

With the spread of globalization, the importance of trust in organizational relations has received wide attention. Therefore, most scholars, from various disciplines, have pointed out the important role of trust in organizations. Studies show that trust creates interpersonal and within personal effects and influences inter and within organization relations. That is why it is said that results in improving job satisfaction, organizational commitment, confidence among staffs, increasing cooperation, information-sharing, problem-solving, facilitating empowering, change potential, organizational innovation and learning, decreasing lack of confidence to future, conflict reconciliation and eventually, creating a framework for organization productivity.

On the other hand, lower organizational trust brings about increasing conflict, organization instability, absenteeism, reducing motivation, setting obstacles in the way of organization objectives, and so on. Cook and Wall [4] believe that trust - in the common language- means an individual tendency to attributing good intentions to others and having trust in their speech and actions. See trust as an individual's expectations, assumptions, or ideas about the possibility that future actions, and defines organizational trust as a construct that contains positive expectations which people specify based on organizational roles, occasions, and mutual interdependencies from different behaviors of organization members.

\section{Organizational Trust}

As we look into the development of human resource management, we would find out that focusing on humans, in the world of management and organizations, has been the focal point of management theorists. This growing attention has increased to the point that, today, human resources, is called organization customers. This means that in the new age, satisfying the basic needs of employees should be first priority in any organization since realizing the goals of organization depends on satisfying logical goals and wants of human resources [1]. One of the most important needs of the staffs in an organization is to establish trust between the staffs and the manager. Creating high levels of trust results in lower evaluation costs, other mechanism of control and the staffs themselves control everything as well as have internal motivation. Given that 
creating trust leads to organization efficiency and decreasing evaluation and control costs, it is necessary to identify factors that result in trust [10]. Organizational commitment of the staffs is also affected by this issue since if management is to reduce absenteeism and leaving the company on the part of the employees, they should take some actions which organization members get positive attitude. If mistrust atmosphere dominates, the positive attitude will fade away. We should keep on mind that achieving strong organizational trust depends on creating and establishing mental association and commitment of the individuals to the organization. Trust incorporates important concepts for studying, and it is the key component of developing inter-personal relations. Low level of trust leads to the fact that employees distort information flow in the organization, open and honest relations fade away, mistrust to be spread and organization decisions not being of desired quality [14]. Trust is a multi-facet concept and is related to interactions of colleagues and teams at different levels.

The organizational trust structures are positive expectation which individuals have experiences and interdependencies of different member behavior based on organization roles [15]. Trust is multi-level concept which plays an important role in all relationships such as friendship, family, organization and economic relations [11]. According to the above, the main purpose of current study is identification of relationship between the general perception of effectiveness and competence members, attention of colleagues, managers and organization, stable and trustable behaviors in organization, explicit environment and the sense of identity of organization [13].

Trust is a strong belief, honesty and power of a person, relying on a claim or opinion [16]. Other research stated that trust is the reliance on others with the possibility of opportunism, uncertainty and their risk [12]. Bakhtiari (2010) introduce trust as a common good which is necessary to being success in economic. The trust is vital element to easily solve problems. Because, it determine that whether members allow others to participate in making decisions [2]. Recently, the concept of trust is increasing in management literature. In most definitions, trust is a key functionality which includes risk management and uncertainty. Trust is different with certainty. Because, judges will be based on trust in uncertainty level [13].

Building trust in the workplace brings about information-sharing, commitment to the decisions, organizational citizenship behavior, improving staff morale, increasing innovation and better management of organizational effectiveness. That is because scholars consider trust management as an important factor in cooperation and conflict, leadership styles, management presuppositions about employees, organization change and progress, involvement and social interactions. Over the past 15 years, trust- as an integral part for organization success- has been at the focal point of organization studies.

Some believe that growing level of studies in the field of trust may be attributed to the fact that organizations suffer from lack of trust among their management and the staffs. So, some solutions should be offered for this problem. If this problem is ignored, it may lay the grounds for many other problems in the future. Since organizations need more capable employees to respond to environmental changes; therefore, empowering the staffs is one of important strategies for better adapting with outside changes.

\section{Organizational Innovation}

The concept of innovation has attracted the attention of many researchers. According to De Jong, this concept was first advanced by Schumpeter in 1934 which is regarded as a process for creating a new brand, products, services, and its effects on economic development. Since then, different scholars addressed this concept deeply to describe long survival of the organizations and innovation was regarded as a valuable component of the organizations. Damanpour, assert that innovation is producing new science and business ideas for marketing new products. Its aim is to improve domestic business processes, market structure and attractions toward products and services. In general, innovation is developing ideas, accepting and implementing new ideas in processes, products and services.it is also tendency to change by adopting technology, resources, skills, and new management systems. Innovation is an important factor in success and competitive advantage of organizations and in a powerful economy [5]. 
The first perspective uses the term "organizational innovation" to mean the adoption of various types of innovation in organizations. The unit of analysis is thus the organization and its characteristics (size, age, structure...) examined to assess their effect on the propensity to innovate. If studies in this vein are useful, their results are still ambiguous in that a factor which is positively related to innovation in one research is negatively related to in another and even stated as insignificant in a third. According to Downs and Mohr [8] this results from a problem of focus on organization rather than specifically on innovation. Indeed, various characteristics of the organization, such as its size, its structure, its managerial type, may play different roles depending on the type of innovation, but also depending on the stage of the process. So, three important critiques can be made about this research perspective. First, it generally focuses on one type of innovation: technological (product and process). Second, it has a static orientation: most of the time, the focus is on adoption decision. Yet innovation determinants may differ depending on adoption process phases [5,7]. And third, the data come solely from the head of organizations and do not necessarily represent the innovation behaviour of the organizations' relevant members.

The second perspective defines OI is itself the unit of analysis but it can be analysed as a result or an output (concrete new practices, concepts, forms, structures) or as a process within which new practices and concepts are considered, decided, put into use and sustained.

When OI is analysed as a process, research investigates its sequences and their corresponding activities as a way to better explore this poorly understood complex social process [3] in order to give coherent advice to managers.

Table 1 summarises the two perspectives (the second one being subdivided into two) giving the definitions of OI, as well as the corresponding core questions and representative papers.

It seems that authors have recently provided a clearer distinction between the two main perspectives. We notice a turning point namely in the Damanpour and Gopalakrishnan [6] paper of 2001 in which the authors propose the terms "adoption of innovations in organizations" for the first perspective when they previously used "organizational innovation" to signal the same meaning. This clear distinction is very important to avoid confusions or amalgams between results that do not address the same concept.

Today, almost all organizations are faced with dynamic environment with features like fast changing technology, decreasing lifecycle of the product and globalization. Organizations (particularly technology-oriented ones) should be more creative and innovative than before in order to survive, compete, grow and progress. There are different definitions for innovation. One of the most widely used one is that innovation is creating new and useful ideas and it is implementing creative ideas in an organization.

\section{Methodology}

Since the purpose of the current research is to analyze relationship between organizational trust with organizational innovation in Payam Nour University in Tehran, so its design is descriptive- survey and is among field study. It should be noted that this kind of research method uses such collecting data techniques as (questionnaires, interviews, document survey) to collect data from statistical samples. The researcher attends the study area personally and collects data and finally tests hypotheses which have offered in advance, based on his or her own evidence and information. Generalizing the result to the whole statistical population is the last step in this research.

\section{Findings}

The purpose of the current research is to analyze relationship between organizational trust with organizational innovation in Payam Nour University in Tehran. 69\% of the sample was male and $31 \%$ were female. $72.7 \%$ were married and $27.3 \%$ were single. 
Table 1. Pearson correlation coefficient between two variables of organizational trust and organizational innovation

\begin{tabular}{|l|l|c|}
\hline \multicolumn{2}{|l|}{$\begin{array}{l}\text { Predictor variable } \\
\text { Criterion variable }\end{array}$} & Organizational trust \\
\hline Organizational trust & Pearson correlation coefficient & 0.664 \\
\hline & $\begin{array}{l}\text { Significance level of two } \\
\text { ranges }\end{array}$ & 0.000 \\
\hline
\end{tabular}

Table 2. Summary of regression model between two variables of organizational trust and organizational innovation

\begin{tabular}{|l|l|l|l|l|}
\hline model & $\begin{array}{l}\text { Correlation } \\
\text { coefficient }\end{array}$ & $\begin{array}{l}\text { Coefficient of } \\
\text { determination }\end{array}$ & $\begin{array}{l}\text { Modified } \\
\text { Coefficient of } \\
\text { determination }\end{array}$ & $\begin{array}{l}\text { Estimated } \\
\text { standard } \\
\text { deviation }\end{array}$ \\
\hline 1 & 0.664 & 0.441 & 0.438 & 0.49415 \\
\hline
\end{tabular}

Table 3. Result of linear regression analysis between two variables of organizational trust and organizational innovation

\begin{tabular}{|c|c|c|c|c|c|c|}
\hline \multirow{2}{*}{\multicolumn{2}{|c|}{ model }} & \multicolumn{2}{|c|}{$\begin{array}{l}\text { Non-standard } \\
\text { coefficient }\end{array}$} & $\begin{array}{l}\text { Standard } \\
\text { coefficient }\end{array}$ & \multirow[t]{2}{*}{$\begin{array}{c}\text { Statistic } \\
\mathrm{t}\end{array}$} & Significance level \\
\hline & & B & $\begin{array}{l}\text { Standard } \\
\text { error }\end{array}$ & $\beta$ & & \\
\hline \multirow[t]{2}{*}{1} & constant & 1.017 & 0.144 & \multirow[t]{2}{*}{0.664} & 7.038 & 0.000 \\
\hline & $\begin{array}{l}\text { Organizational } \\
\text { trust }\end{array}$ & 0.670 & 0.050 & & 13.434 & 0.000 \\
\hline
\end{tabular}

Table 4. Pearson correlation coefficient between two variables of integrity and organizational innovation

\begin{tabular}{|l|l|l|}
\hline \multicolumn{2}{|l|}{$\begin{array}{l}\text { Predictor variable } \\
\text { Criterion variable }\end{array}$} & integrity \\
\hline Organizational innovation & Pearson correlation coefficient & 0.517 \\
\cline { 2 - 3 } & $\begin{array}{l}\text { Significance level of two } \\
\text { ranges }\end{array}$ & 0.000 \\
\hline
\end{tabular}

Given the result in Table 4, correlation coefficient between these two variables is $(\mathrm{r}=.52 \%)$. So, there is direct relationship between these two variables. That is, in general, by increasing level of integrity, organizational trust is also increased. In behavioral science, this correlation coefficient is regarded as an average correlation coefficient regardless of its symbol. Considering that $(\mathrm{P}=0.01)$ Sig $<0.01$, it can said by $99 \%$ confidence that the relationship between these two variables is significant. Therefore, we can predict organizational innovation based on integrity and regression equation was run for these two variables.

Table 5. Summary of regression model between two variables of integrity and organizational innovation

\begin{tabular}{|l|l|l|l|l|}
\hline model & \multicolumn{1}{|c|}{$\begin{array}{c}\text { Correlation } \\
\text { coefficient }(\mathrm{R})\end{array}$} & $\begin{array}{c}\text { Coefficient of } \\
\text { determination } \mathrm{R}^{2}\end{array}$ & $\begin{array}{c}\text { Modified } \\
\text { Coefficient of } \\
\text { determination }\end{array}$ & $\begin{array}{c}\text { Estimated } \\
\text { standard } \\
\text { deviation }\end{array}$ \\
\hline 1 & 0.517 & 0.267 & 0.264 & 0.56578 \\
\hline
\end{tabular}


Table 6. Result of linear regression analysis between two variables of integrity and organizational innovation

\begin{tabular}{|c|c|c|c|c|c|c|}
\hline \multirow{2}{*}{\multicolumn{2}{|c|}{ model }} & \multicolumn{2}{|c|}{$\begin{array}{l}\text { Non-standard } \\
\text { coefficient }\end{array}$} & $\begin{array}{l}\text { Standard } \\
\text { coefficient }\end{array}$ & \multirow[t]{2}{*}{$\begin{array}{c}\text { Statistic } \\
\mathrm{t}\end{array}$} & \multirow[t]{2}{*}{ Significance level } \\
\hline & & $\mathrm{B}$ & $\begin{array}{l}\text { Standard } \\
\text { error }\end{array}$ & $\beta$ & & \\
\hline \multirow[t]{2}{*}{1} & constant & 1.821 & 0.125 & \multirow[t]{2}{*}{0.517} & 14.596 & 0.000 \\
\hline & integrity & 0.387 & 0.042 & & 9.129 & 0.000 \\
\hline
\end{tabular}

Table 7. Pearson correlation coefficient between two variables of reliability and organizational innovation

\begin{tabular}{|l|l|l|}
\hline $\begin{array}{l}\text { Predictor variable } \\
\text { Criterion variable }\end{array}$ & reliability \\
\hline Organizational innovation & Pearson correlation coefficient & 0.713 \\
\hline & $\begin{array}{l}\text { Significance level of two } \\
\text { ranges }\end{array}$ & 0.000 \\
\hline
\end{tabular}

Given the result in Table 7, correlation coefficient between these two variables is $(r=.71 \%)$. So, there is direct relationship between these two variables. That is, in general, by increasing level of reliability, organizational trust is also increased. In behavioral science, this correlation coefficient is regarded as an average correlation coefficient regardless of its symbol. Regarding that $(\mathrm{P}=0.01)$ Sig $<0.01$, it can said by $99 \%$ confidence that the relationship between these two variables is significant. Thus, we can predict organizational innovation based on reliability and regression equation was run for these two variables.

Table 8. Summary of regression model between two variables of reliability and organizational innovation

\begin{tabular}{|l|l|l|l|l|}
\hline model & $\begin{array}{l}\text { Correlation } \\
\text { coefficient }(\mathrm{R})\end{array}$ & $\begin{array}{l}\text { Coefficient of } \\
\text { determination } \mathrm{R}^{2}\end{array}$ & $\begin{array}{l}\text { Modified } \\
\text { Coefficient of } \\
\text { determination }\end{array}$ & $\begin{array}{l}\text { Estimated } \\
\text { standard } \\
\text { deviation }\end{array}$ \\
\hline 1 & 0.713 & 0.508 & 0.506 & 0.46325 \\
\hline
\end{tabular}

Table 9. Result of linear regression analysis between two variables of reliability and organizational innovation

\begin{tabular}{|c|c|c|c|c|c|c|}
\hline \multirow{2}{*}{\multicolumn{2}{|c|}{ model }} & \multicolumn{2}{|c|}{$\begin{array}{l}\text { Non-standard } \\
\text { coefficient }\end{array}$} & \multirow{2}{*}{$\begin{array}{l}\text { Standard } \\
\text { coefficient } \\
\beta\end{array}$} & \multirow[t]{2}{*}{$\begin{array}{c}\text { Statistic } \\
\mathrm{t}\end{array}$} & \multirow[t]{2}{*}{ Significance level } \\
\hline & & $\mathrm{B}$ & $\begin{array}{l}\text { Standard } \\
\text { error }\end{array}$ & & & \\
\hline \multirow[t]{2}{*}{1} & constant & 0.883 & 0.135 & \multirow[t]{2}{*}{0.713} & 6.538 & 0.000 \\
\hline & reliability & 0.692 & 0.045 & & 15.392 & 0.000 \\
\hline
\end{tabular}

Table 10. Pearson correlation coefficient between two variables of organizational commitment and organizational innovation

\begin{tabular}{|l|l|l|}
\hline $\begin{array}{l}\text { Predictor variable } \\
\text { Criterion variable }\end{array}$ & Organizational commitment \\
\hline Organizational innovation & Pearson correlation coefficient & 0.524 \\
\hline & $\begin{array}{l}\text { Significance level of two } \\
\text { ranges }\end{array}$ & 0.000 \\
\hline
\end{tabular}


According to the result of Table 10, correlation coefficient between these two variables is $(\mathrm{r}=.52 \%)$. So, there is direct relationship between these two variables. That is, in general, by increasing organizational commitment, organizational trust is also increased. In behavioral science, this correlation coefficient is regarded as an average correlation coefficient regardless of its symbol. Given that $(\mathrm{P}=0.01) \mathrm{Sig}<0.01$, it can said by $99 \%$ confidence that the relationship between these two variables is significant. Thus, we can predict organizational innovation based on organizational commitment and regression equation was run for these two variables.

Table 11. Summary of regression model between two variables of organizational commitment and organizational innovation

\begin{tabular}{|l|l|l|l|l|}
\hline model & $\begin{array}{l}\text { Correlation } \\
\text { coefficient }(\mathrm{R})\end{array}$ & $\begin{array}{l}\text { Coefficient of } \\
\text { determination } \mathrm{R}^{2}\end{array}$ & $\begin{array}{l}\text { Modified } \\
\text { Coefficient of } \\
\text { determination }\end{array}$ & $\begin{array}{l}\text { Estimated } \\
\text { standard } \\
\text { deviation }\end{array}$ \\
\hline 1 & 0.524 & 0.274 & 0.271 & 0.56297 \\
\hline
\end{tabular}

Table 12. Result of linear regression analysis between two variables of organizational commitment and organizational innovation

\begin{tabular}{|c|c|c|c|c|c|c|}
\hline \multirow{2}{*}{\multicolumn{2}{|c|}{ model }} & \multicolumn{2}{|c|}{$\begin{array}{l}\text { Non-standard } \\
\text { coefficient }\end{array}$} & $\begin{array}{l}\text { Standard } \\
\text { coefficient }\end{array}$ & \multirow[t]{2}{*}{$\begin{array}{l}\text { Statistic } \\
\mathrm{t}\end{array}$} & \multirow[t]{2}{*}{$\begin{array}{l}\text { Significance level } \\
\text { Sig. }\end{array}$} \\
\hline & & B & $\begin{array}{l}\text { Standard } \\
\text { error }\end{array}$ & $\beta$ & & \\
\hline \multirow[t]{2}{*}{1} & constant & 1.720 & 0.133 & \multirow[t]{2}{*}{0.524} & 12.929 & 0.000 \\
\hline & reliability & 0.419 & 0.045 & & 9.299 & 0.000 \\
\hline
\end{tabular}

Table 13. Pearson correlation coefficient between two variables of qualification and organizational innovation

\begin{tabular}{|l|l|l|}
\hline $\begin{array}{l}\text { Predictor variable } \\
\text { Criterion variable }\end{array}$ & qualification \\
\hline Organizational innovation & Pearson correlation coefficient & 0.556 \\
\hline & $\begin{array}{l}\text { Significance level of two } \\
\text { ranges }\end{array}$ & 0.000 \\
\hline
\end{tabular}

Considering the result of Table 11, correlation coefficient between these two variables is $(\mathrm{r}=.56 \%)$. So, there is direct relationship between these two variables. That is, in general, by increasing qualification, organizational trust is also increased. In behavioral science, this correlation coefficient is regarded as an average correlation coefficient regardless of its symbol. Given that $(\mathrm{P}=0.01)$ Sig $<0.01$, it can said by $99 \%$ confidence that the relationship between these two variables is significant. Thus, we can predict organizational innovation based on qualification and regression equation was run for these two variables.

Table 14. Summary of regression model between two variables of organizational commitment and organizational innovation

\begin{tabular}{|l|l|l|l|l|}
\hline model & $\begin{array}{l}\text { Correlation } \\
\text { coefficient }(\mathrm{R})\end{array}$ & $\begin{array}{l}\text { Coefficient of } \\
\text { determination } \mathrm{R}^{2}\end{array}$ & $\begin{array}{l}\text { Modified } \\
\text { Coefficient of } \\
\text { determination }\end{array}$ & $\begin{array}{l}\text { Estimated } \\
\text { standard } \\
\text { deviation }\end{array}$ \\
\hline 1 & 0.556 & 0.309 & 0.306 & 0.54922 \\
\hline
\end{tabular}


Table 15. Result of linear regression analysis between two variables of qualification and organizational innovation

\begin{tabular}{|c|c|c|c|c|c|c|}
\hline \multirow{2}{*}{\multicolumn{2}{|c|}{ model }} & \multicolumn{2}{|c|}{$\begin{array}{l}\text { Non-standard } \\
\text { coefficient }\end{array}$} & $\begin{array}{l}\text { Standard } \\
\text { coefficient }\end{array}$ & \multirow[t]{2}{*}{$\begin{array}{c}\text { Statistic } \\
\mathrm{t}\end{array}$} & \multirow[t]{2}{*}{ Significance level } \\
\hline & & $\mathrm{B}$ & $\begin{array}{l}\text { Standard } \\
\text { error }\end{array}$ & $\beta$ & & \\
\hline \multirow[t]{2}{*}{1} & constant & 1.335 & 0.160 & \multirow[t]{2}{*}{0.556} & 8.363 & 0.000 \\
\hline & reliability & 0.584 & 0.058 & & 10.122 & 0.000 \\
\hline
\end{tabular}

\section{Conclusion}

In this study the relationship between organizational trust and organizational innovation was analyzed theoretically in Payam Nour University in Tehran and then it was tested. The purpose of this research was to analyze the effect of each of these variables and their components on organizational innovation. To test the mentioned hypotheses, and calculating the level of correlation between two variables of organizational trust and organizational innovation, Pearson correlation coefficient was used. Given the result of this test which is shown in the following tales, correlation coefficient between these two variables $(\mathrm{r}=0.66 \%)$ so, there is direct relationship between these two variables. Namely, by increasing organizational trust, organizational innovation is also increased.

The results of this study are in agreement with findings of Gholipour [9] studies. Musca predicted that the features of the third millennium are creativity and development and organizations will provide environments with dynamic relations full of trust between superordinate and subordinates. Golipour, Bidalt and Alonen asserted that effect of institutional trust is more than that of other kinds of organizational innovation. Given that the present research is a case study and studies only Payam Nour University o Tehran, it is suggested that the proposed research model be tested in a larger statistical population so that more generalizable results can be achieved. In addition, to complement research model, it is proposed that besides organizational trust and innovative leadership, the effects of other factors be investigated in the future studies.

- It is suggested to the managers of the organizations to take their promises seriously in order to create an environment full of trust. Such an environment lays the foundation for creativity and innovation. Lieberman calls integrity the most important factor of trust.

- Managers of the organizations should express honesty by creating open relationship with the staffs so that they will have a clear understanding of the present situation, analyze it and go toward the desired objectives.

- Another important suggestion is to tell the truth properly and at the right time. Since expressing reality between staffs and management creates considerable trust which, in turn, lays the foundation for risky and innovative actions.

\section{References}

[1]Abtahi, Human resources management. Tehran: Institute of research and management Education, 2004.

[2]M. Bakhtiari, The survey of social trust and it's effective factors. Master Thesis social sciences, Isfahan university, 2010.

[3]J. Birkinshaw, G. Hamel, M. J. Mol, Management innovation, Academy of Management Review. 33(4) (2008) 825-845.

[4]J. Cook, T. D. Wall, New wok attitude measures of trust, organizational commitment and personal need non-fulfillment, Journal of Occupational psychology. 53 (1980) 39-52. 
[5]F. Damanpour, The adoption of technological, administrative, and ancillary innovations: impact of organizational factors, Journal of Management. 13(4) (1987) 675-688.

[6]F. Damanpour, S. Gopalakrishnan, The dynamics of product and process innovations in organizations, Journal of Management Studies. 38(1)(2001) 45-65.

[7]F. Damanpour, M. Schneider, Phases of the Adoption of Innovation in Organizations: Effects of Environment, Organization and Top Managers, British Journal of Management. 17(3)(2006) 215-236.

[8]G. Downs, L. Mohr, Conceptual issues in the study of innovations, Administrative Science Quarterly. 21(4)(1976) 700-714.

a. Gholipour, Effect of responsible leadership on organizational trust and empowering in governmental agencies, Journal of governmental management. 2(2009) 88-103.

[9]H. Hassanzadeh, Identifying effective factors on creating trust between staffs and managers and investigating executive organizations of Iran”, MA thesis, Tehran University, Pardis of Qom, 2009.

[10] D. Lusher, G. Robins, P. E. Pattison, A. Lomi, Trust Me: Differences in expressed and perceived trust relations in an organization, Social Networks. 34 (4)(2012) 410-424.

[11] Mystal, The survey of the concept of trust among classic sociologists. Naseredin Gharab, The journal of Namayeh research. 5(48)(2001) 55-68.

[12] G. PourAhmadi, A. Ahmadizad, The relationship between internal organizational trust and job engagement in Higher Education, International Letters of Social and Humanistic Sciences. 64(2015) 94-101.

[13] Z. Sarmad, A. Bazargan, E. Hejazi, Research Methods in behavioral science. Tehran: Agah Publication, 2016.

[14] P. Shockley-Zalabak, K. Ellis, G. Winograd, Organizational trust: What it means, why it matters, Organizational Development Journal. 18(4)(2000)35 - 49.

[15] P. Zetomka, Sociological theory of trust. Tehran: Shirazeh publication, 2007. 